\title{
Factors Affecting Customer Satisfaction and Customer Loyalty towards Belle Footwear Company in Lanzhou City, Gansu Province of the People's Republic of China
}

\author{
Jiao $\mathrm{Li}^{1}$ \\ I'MBA DAY, Assumption University, Thailand)
}

\begin{abstract}
The shoe industry in China now faces grim challenges due to rapidly changing tastes of shoe buyers and fierce competition in the footwear market. Besides, shoes marketers are increasingly concerned about how to keep the good and long term relationship with customers and also increase customer loyalty at shoe stores. This research focuses on customer satisfaction and customer loyalty of footwear products in Lanzhou, China. The purpose of this research is to explore the possible antecedents of customer loyalty among Belle shoes store customers. The researcher theorizes and investigates that there is a positive relationship between image, price, perceived quality (in terms of reliability, tangibles, empathy, responsiveness and assurance) and perceived value with customer satisfaction, which in turn, significantly influences customer loyalty towards Belle Footwear Company. 400 self-administered questionnaires were distributed to respondents. The results of this study indicate that all independent variables (image, price, reliability, tangibles, empathy, responsiveness, assurance and perceived value) have a significant relationship with the intervening variable (customer satisfaction) and dependent variable (customer loyalty). Shoe marketers will have a better understanding about Chinese consumers and also could learn to improve their strategies to improve their product quality and gain more customers to extend their market size.
\end{abstract}

Keywords: Customer satisfaction, customer loyalty, footwear, perceived value, perceived quality

\section{Introduction}

In this study, the researcher intends to focus in is China's footwear market. In recent years, the footwear industry and the business environment have significantly changed and have also become more sophisticated and competitive, specifically in Lanzhou, Gansu. This study focuses on Belle International Footwear Company, the biggest footwear and sportswear manufacturer in China, to analyze how this company uses customer loyalty factors to achieve a huge sales volume and compete with other international brands. This study also assesses how this company can strengthen its position in the market for shoes in China.

Today in the footwear industry, the reflection of how consumers perceptions make a good brand impression on customers has become more and more important. Image can be held in memory by various associations (de Chernatony and McDonald, 2003; Keller, 2008), with it being stated that it is a shared subconscious mental picture (Reizebos, 2003).

As price often sends quality cues to customers, low prices of a product reflect the perceptions of quality (Jobber, 2010), underlining that repeat purchases at certain footwear stores do not depend on quality but on price. Customers often use their perceived value to compare the differences between perceived benefits and sacrifices (Zeithaml, 1988 ; McDougall and Levesque, 2000).

Perceived quality is an attitude formed when customers compare the difference between expectations with the actual performance (Parasuraman et al., 1985). For footwear companies, the perceived benefits help produce customer satisfaction and keep customer loyalty (Hennig-Thurau et al., 2002). Customer satisfaction can generate positive comments and feedback which affects repeat purchases from consumers. Customer loyalty depends to a great extent on customization of service (Ball et al., 2006) and making the customer enjoy shopping at a particular footwear store (Wong, 2004). That is why customer satisfaction and loyalty are very important to Belle international company's future. With the recent changes in footwear trends, this study hopes to analyze all possible effects of factors on the brand image, price, perceived value, service quality, customer satisfaction and loyalty of Belle footwear store in Lanzhou.

The market for shoes is highly competitive everywhere, in this study, the researcher would focus on customer satisfaction in order to build customer loyalty. Meanwhile, with an increase in competitiveness and unpredictability in the markets for shoes, the major key for success in footwear business is customer loyalty.

2.1 Customer Loyalty

\section{Literature Review}

Oliver (1997) defined loyalty as a deeply held commitment to re-buy or re-patronize a preferred product or 
service consistently in the future. Recent studies have conceptualized customer loyalty on the basis of both behavioral and attitudinal aspects (Evanschitzky and Wunderlich, 2006; Fitzgibbon and White, 2005; Olsen et al., 2005; Yi and La, 2004). Customer loyalty is divided into two possible ways: one is aspect is the behavior of customers, which is demonstrated by repetitive purchases of the same brand, a preference of a brand and the recommendation of the brand to others; another aspect is the attitude of customers, which is the internal affect and perception components of customer loyalty. Customers may exhibit repurchase behavior due to limited choice available or inertia (Bloemer and Kasper, 1995). Customers have exhibited, over a recent period, much repeat purchases of Belle company products and significant spending for Belle shoes in terms of the customer's total outlay. Real customer loyalty extends beyond behavior and includes preference and desire (Lovelock and Wirtz, 2007).

\subsection{Customer Satisfaction}

Customer satisfaction is defined as customers' needs and goals when a service is providing a pleasurable level of fulfillment and emotional response (Oliver, 1997). Customer satisfaction is an important factor to understand to satisfy customers about what they need and want. Pleasurable means that fulfillment increases pleasure or reduces displease or anxiety. Fulfillment is determined by the customers' expectations. Moreover, if the perceived service performance does not meet customer expectations, the likely result is dissatisfaction (Churchill and Surprenant, 1982; Oliver, 1980; Yi, 1990). The level of satisfaction or dissatisfaction is reflected from perceptions and attitudes from previous service experiences, and may also influence repurchase intentions (McGuire, 1999).

Customer satisfaction is a significant element in service delivery because understanding and satisfying customers' needs and wants can engender increased market share from repeat purchases and referrals (Barsky, 1992). Overall contentment felt by the customer results from the ability of the service to fulfill the customer's desires, expectations and needs in relation to the service. Customer satisfaction is rated highly as a strategic end in and of itself, as it affects customer retention and profits directly (Jones and Sasser, 1995; Reichheld, 1996). Customer satisfaction will affect future repeat purchase intentions and the customers will share their positive experiences with other consumers.

\subsection{Perceived Value}

Perceived value has been defined as the benefit from services which customers believe they receive in consideration for the cost of that service (McDougall and Levesqu, 2000). Rust and Oliver (1994) stated that if the price was too high and a service is of a good quality, then customers rated it as a poor value service. Heskett et al. (1997) found that high value was not necessary associated with low prices, because services with a high perceived value may in fact have high or low prices. When perceived value increases, maybe customers will stay loyal and have increased expectations, whereas a decrease in value will result in customers being more receptive to competitors' marketing (Grönroos, 2000).

Companies can employ two strategies, one is adding more benefits from their services, and another is reducing the costs associated with the purchase that will enhance the customers' perceived value (Lovelock and Wirtz, 2007). Perceived value is the trade-off between what customers receive and what they have to pay to obtain a service (Monroe, 1991; Zeithaml, 1988). Customer perceived costs are often represented and measured by price (Brady and Cronin, 2001; Lam et al., 2004; Sweeney et al., 1999; Varki and Colgate, 2001; Wang et al., 2004). Other non-monetary costs include time and physical and mental effort (Zeithaml et al., 2009). These types of costs are different across individual consumers and situations (Tam, 2004).

\subsection{Image}

Keller (1993) stated that image is based upon the customers' beliefs about a brand and its associations held in memory and that the image comes from the perceptions of the consumers. In the marketing services, image was identified as a significant factor in a company's overall evaluation (Bitner, 1991; Grönroos, 1984; Gummesson and Grönroos, 1988). Image has been described as an individual knowledge such as an attitude or a combination of product characteristics that's identified by product and it is different from the product physical characteristics (Nguyen \& LeBlanc, 1998). And image has also been described as the overall impression left in the minds of customers (Zimmer \& Golden, 1988). According to Grönroos (1984), image was defined as a filter that affects the perception of a company operation. The overall image of the company is affected it's by perceived value, service quality and customer satisfaction.

\subsection{Price}

Price is a major determinant of consumer choice (Kotler et al., 2009). That is it's the cost incurred in making a purchase (Tse, 2001), which together with perceived service quality and perceived value influence spending behavior (Rust and Oliver, 1994). Consumers will determine what price can be paid based upon their 
discretionary spending limits (Monroe, 1990). How much a customer is willing to pay depends on what they need, what they expect and their evaluation of the quality of a service at its given time and place (Heskett et al., 1997). High price products and services are believed to be high-quality products and services and their prices are normally higher than lower-quality equivalent products or services as price impacts perceived quality (Curry and Riesz, 1988; Erickson and Johansson, 1985; Lichtenstein et al., 1988). If consumers have no experience in obtaining a service, they therefore make a decision based upon their expectation, image, perception of quality and price (Dodds et al., 1991; Monroe, 1990; Zeithaml et al., 1990).

\subsection{Perceived Quality}

Perceived quality is judgment superiority by customers about a product's overall excellence or (Zeithaml, 1988) it's like an attitude (Zeithaml, 1988; Parasuraman et al., 1985). Perceived quality is defined as the customers compare between their expectation and perception of service performance (Lehtinen \& Lehtinen, 1982; Lewis \& Booms, 1983, Gronroos, 1984; Parasuraman et al., 1985; 1988; Caruana, 2002).

\subsubsection{Reliability:}

Parasuraman et al. (1988) defined reliability as the ability of a firm to perform the promised service dependably and accurately. Zeithaml et al. (2006) mentioned that this dimension is critical as customers want to deal with a company that keep its promises with as all its customers and generally simply show that company has good communication with them. Nguyen \& Leblanc (2001) mentioned that, considering reputation about reliability, customers' past experiences are related to the reliability of service quality (Ndubisi, 2006).

\subsubsection{Tangibles:}

Tangibles have been defined as personal appearance, physical facilities like store decorations, display and equipment (Parasuraman et al., 1988). It refers to the shoes interior, the appearance and condition of the shelf space, uniform of the staff, the appearance and design of the brochure, the store's sign and its advertisements (Zeithamal et al., 2006). Tangibles are basic elements such as access to the facilities and the safety and convenience for customers (Bellini et al., 2005). Tangibles are used by firms to convey their image and signal quality (Zeithaml et al., 2006).

\subsubsection{Empathy:}

Parasuraman et al. (1988) and Zeithaml et al. (2006) defined empathy as the firms` personalized attention for their customers and for giving them care and assistance. This dimension is also more suitable to companies that are trying to build a relationship with customers as opposed to "transaction marketing". This ensures the firms survival (Andaleeb \& Conway, 2006). Empathy has several ways that can be shown to customers such as knowing the customer's name, preferences and needs. Many companies use this competence to provide customized services as a competitive advantage over other firms (Zeithaml et al., 2006).

\subsubsection{Responsiveness:}

According to Parasuraman et al. (1988), responsiveness is the employees express willingness to help customers and provide quick service. This dimension is concerned with dealing with the customer's requests, questions and complaints promptly and attentively. When it communicates to its customers, a firm needs to know how to be responsive and how long it would take to get answers and solve problems. If companies want to be successful, they needs to look at the view point of the customer rather than the company's perspective (Zeithaml et al., 2006).

\subsubsection{Assurance:}

Parasuraman et al. (1988) defined assurance as the trained courtesy of employees and also the ability to inspire trust and confidence from them. According to Zeithaml et al. (2006), assurance represented the personnel who link the customer to the organization by trust and confidence. It's about traditional selling and relationship marketing expressed information and shared understanding to customer (Ndubisi, 2006; Lymperopoulos et al., 2006). 


\section{Conceptual Framework and Research Hypotheses}

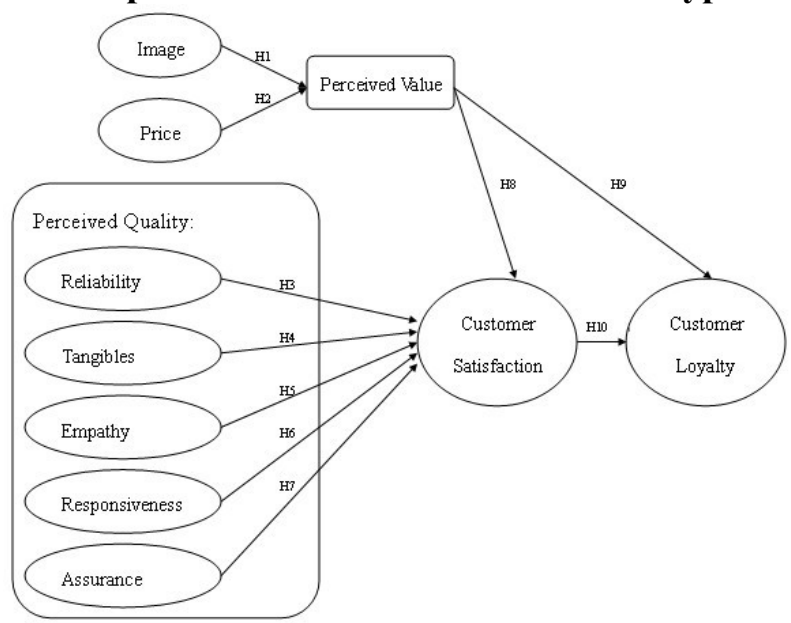

Figure 1: modified conceptual framework

This conceptual framework is designed to analyze the circumstances that affect customer loyalty for Belle brand in order to understand which variable is most important in the formation of customer loyalty. The research hypotheses were developed based on the conceptual framework of the study to provide a clear implication from relationship testing. Therefore, in order to make it clear in terms of hypothesis setting, the hypotheses were divided into three groups. All hypotheses are as follows:

Group 1: The relationship between image and price with perceived value

$\mathrm{H}_{0}$ : There is no relationship between image and perceived value.

$\mathrm{H}_{\mathrm{a}}$ : There is a relationship between image and perceived value.

$\mathrm{H} 2{ }_{0}$ : There is no relationship between price and perceived value.

$\mathrm{H} 2{ }_{\mathrm{a}}$ : There is a relationship between price and perceived value.

Group 2: The relationship between perceived service quality in terms of reliability, tangibles, empathy, responsiveness and assurance with customer satisfaction

$\mathrm{H}_{3}$ : There is no relationship between perceived quality in terms of reliability and customer satisfaction.

$\mathrm{H}_{\mathrm{a}}$ : There is a relationship between perceived quality in terms of reliability and customer satisfaction.

$\mathrm{H}_{0}$ : There is no relationship between perceived quality in terms of tangibles and customer satisfaction.

$\mathrm{H}_{4}$ : There is a relationship between perceived quality in terms of tangibles and customer satisfaction.

$\mathrm{H}_{5}$ : There is no relationship between perceived quality in terms of empathy and customer satisfaction.

$\mathrm{H} 5 \mathrm{a}$ : There is a relationship between perceived quality in terms of empathy and customer satisfaction.

$\mathrm{H6}_{6}$ : There is no relationship between perceived quality in terms of responsiveness and customer satisfaction.

$\mathrm{Hb}_{\mathrm{a}}$ : There is a relationship between perceived quality in terms of responsiveness and customer satisfaction.

$\mathrm{H} 7_{0}$ : There is no relationship between perceived quality in terms of assurance and customer satisfaction.

$\mathrm{H} 7_{\mathrm{a}}$ : There is a relationship between perceived quality in terms of assurance and customer satisfaction.

Group 3: The relationship between perceived value, customer satisfaction and customer loyalty

$\mathrm{H} 8_{0}$ : There is no relationship between perceived value and customer satisfaction.

$\mathrm{H} 8 \mathrm{a}$ : There is a relationship between perceived value and customer satisfaction.

$\mathrm{H} 9_{0}$ : There is no relationship between perceived value and customer loyalty.

$\mathrm{H} 9_{\mathrm{a}}$ : There is a relationship between perceived value and customer loyalty.

$\mathrm{H} 10_{0}$ : There is no relationship between customer satisfaction and customer loyalty.

$\mathrm{H} 10_{\mathrm{a}}$ : There is a relationship between customer satisfaction and customer loyalty.

\section{Research Methodology}

This study has adopted a descriptive research method and a survey method. This descriptive research is designed to describe the characteristics of Chinese consumers, which is sought by the researcher to determine the answer who, what, when, where and how questions (Zikmund 2003). In this study, the researcher applied a survey technique by distributing questionnaires to gain feedback from respondents and to gain more understanding about customer loyalty of Belle customers in China. According to Zikmund (1994), a survey technique can gather data from a sample of people by using a questionnaire. Therefore, this survey uses self-administered questions obtained from the respondents in Lanzhou (China) to collect data. The questionnaire 
was developed to study customers of Belle International Footwear Company in Lanzhou, Gansu Province China. A target population is the group of people who have the information that the researcher looks for and from which conclusions and results can be acquired (Birks et al., 2007). In this case, the target population would mostly be the respondents who had purchased Belle footwear products and who had an experience of more than two years with Belle footwear.

Non-probability sampling method was used three steps.

First, judgmental Sampling was collected the data based from the ten popular shopping malls in Lanzhou which had Belle franchised stores: Guofang Mall, Yaou Emporium, Wangfujing Mall, Xidan Mall, New World Mall, Fashion Parkson, Meilun, Wanshang, Hualian Emporium and Baian Shopping Mall.

Second, quota sampling was used to divide the 400 questionnaires in total to and an equal or proportionate representation. Therefore, with a sample size of 400 questionnaires and ten department stores, it means the researcher needed to distribute 40 questionnaires $(400 / 10=40)$ at each store for gaining a greater accuracy and to minimize errors by setting and filing quota controls.

Third, convenience Sampling was distributed directly to consumers in ten Belle franchised stores, of around 40 respondents for each store.

Third, convenience sampling method chooses respondents by finding Belle customers who are the target population and most conveniently available to complete the questionnaire.

The questionnaire contains five parts.

The first part of the questionnaire is a screening question, in order to select the accurate respondent for this research. In the second to the fifth part of the study, the researcher applied the five-points Likert-scale for research instruments. The researcher then used a five-point Liker-scale in the second to fifth parts of the questionnaire for evaluating customer loyalty towards the Belle brand in its store franchises. The researcher used identical questionnaires as the instrument to gather the data from the sample of people which involved both male and female customers from ten different Belle departmental stores. This questionnaire was used to gather the necessary data from the targeted group of respondents and was designed based on the conceptual framework to test the relationship between each variable.

\section{Results and Conclusions}

As shown in Table 1 (see Appendix One), for the demographic factors of this research, the majority of respondents were aged between 26 to 30 years old at 33\%. Respondent's monthly income was between 2501 RMB to 3500 RMB which accounted for $40.3 \%$. For the education level, the highest percentage was bachelor's degree with $34.5 \%$.

For the hypothesis testing part is summarized in Table 2 (see Appendix Two), the researcher concludes that image, price, perceived quality (in terms of reliability, tangibles, empathy, responsiveness and assurance) have statistically significant influences on perceived value and customer satisfaction. Moreover, from the hypothesis testing results, both perceived value and customer satisfaction toward the footwear stores proved to be positively associated with customer loyalty.

The data was analyzed by SPSS (statistical package of social science) to test the 10 hypotheses in groups 1, 2 and 3. The outcome of group 1 shows that there was a relationship between image, price and perceived value. The results with respect to group 2 indicate that there is a relationship between perceived quality in term of reliability, tangibles, empathy, responsiveness and assurance with customer satisfaction. The findings pertaining to group 3 show that there is a relationship between perceived value, customer satisfaction and customer loyalty.

\section{Recommendations}

All the positive ten hypotheses were validated by the research findings. As such there are a number of recommendations that can be given in line with each of the group.

The result of group 1 from hypothesis one and two shows that there is a relationship between image and price with perceived value. Image (H1) and price (H2) does indeed have a positive influence upon perceived value at a moderate level. Both image and price positively impact perceived value, and price is the most influential determinant of perceived value (.608). As such it can be recommended that the marketers must assess the total customer value and total customer cost associated with each competitor's offer in order to know how their offer prices in the consumer's mind. Belle Company has to strengthen and augment the offer's product, services and image benefits. The researcher founded that image (0.599) was concerned that belle stores should provide positive perceived image to consumers and design marketing strategies such as advertising, direct mail, trade press, word-of-moth communication and promotion activities that convey a good reputation with the brand image to their target market. Price also can affect perceived value it the relationship is not very strong. Therefore, if the company wants to change to have a strong relationship, Belle Company must improve product quality and designs to influence consumers' perceived value because price is found to have only a moderate positive 
relationship with perceived value.

The result of group 2 from hypothesis three to hypothesis seven show that there is a relationship between perceived service quality (in term of reliability, tangibles, empathy, responsiveness and assurance) with customer satisfaction. Reliability (H3), tangibles (H4), empathy (H5), responsiveness (H6), assurance (H7) does indeed have a positive influence upon customer satisfaction at a strong level. Each term has a positive impact on customer satisfaction and assurance is the most influential determinant of customer satisfaction (.790). The researcher would like to suggest that the company has to improve their service quality of tangible, from five sub-variables which found that tangibility was concerned with environmental psychology. Therefore, the company should improve the visually pleasing appearance of Belle store and its personnel need to dress neatly as Belle's employees. Belle should consider improving employee communication skills with training programs to enable them in assisting customers and providing them with relevant information about shoes. Thus, belle store may gain a greater chance in attracting customers to make their own final purchase decision. Moreover, Belle store may consider improving their product and service quality, keeping more attention to their customers to satisfy them in the long term.

The result of group 3 from hypothesis eight to hypothesis ten shows that there is a relationship between perceived value and customer satisfaction with customer loyalty. Perceived value (H8) and customer satisfaction (H10) does indeed have a positive influence upon customer loyalty at a strong level. Perceived value impacts both customer satisfaction and customer loyalty, and customer satisfaction is also the most influential determinant of customer loyalty (.719). In order to effectively influence customer loyalty, it is important that Belle company understand how best to improve the perception of value to satisfy customers. Customers would evaluate Belle's store performance mainly on the basis of both perceived value and perceived quality. If the marketers know how best to outperform in both perceived value and perceived quality, this could enhance customers satisfaction and customers loyalty towards Belle company. Since today's consumers change tastes for shoes rapidly, Belle's marketers should improve the shoes to have a fashion-forward design and offer more quality to attract customers. In addition, image and price associated with branding should be used to exert maximum influence via perceived value on customer satisfaction and build long-term loyalty to Belle customers.

\section{References}

[1]. L. De Chernatony, M. McDonald, Creating Powerful Brands in Consumer, Service and Industrial Markets, 3rd ed., (Elsevier, Oxford, 2003)

[2]. K.L. Keller, Strategic Brand Management: Building, Measuring and Managing Brand Equity, 3rd ed., (Prentice-Hall, Englewood Cliffs, NJ, 2008)

[3]. R. Reizebos, Brand Management (Ed.), FT Prentice-Hall, (Harlow, 2003)

[4]. D. Jobber, Principles and Practices of Marketing, 6th ed., (McGraw-Hill Education, Maidenhead, 2010)

[5]. V.A. Zeithaml, Consumer perceptions of price, quality and value: a means-end model and synthesis of evidence, Journal of Marketing, Vol. 52, July,1988, pp. 2-22.

[6]. G. H. G. McDougall, T. Levesque, Customer satisfaction with services: Putting perceived value into the equation. Journal of Services Marketing. 14 (5), 2000, $392-410$.

[7]. Parasuraman, V.A. Zeithaml, L.L. Berry, A conceptual model of service quality and its implications for future research. Journal of Marketing, 49, 1985, Fall.

[8]. T. Hennig-Thurau, K.P. Gwinner, D.D. Gremler, Understanding relationship marketing outcomes: an integration of relational benefits and relationship quality, Journal of Service Research, Vol. 4 No. 3, 2002, pp. 230-47.

[9]. D. Ball, P.S. Coelho, and M.J. Vilares, Service personalization and loyalty, Journal of Services Marketing, Vol. 20 No. 6, 2006 , pp. 391-403.

[10]. Wong, The role of emotional satisfaction in service encounters, Managing Service Quality, Vol. 14 No. 5, 2004, pp. 365-76.

[11]. R. Oliver, Satisfaction: A Behavioral Perspective on the Consumer (McGraw-Hill, Maidenhead, 1997).

[12]. H. Evanschitzky, and M. Wunderlich, An examination of moderator effects in the four-stage loyalty model, Journal of Service Research, Vol. 8 No. 4, 2008, pp.330-45.

[13]. Fitzgibbon, and L. White, The role of attitudinal loyalty in the development of customer relationship management strategy within service firms, Journal of Financial Services Marketing, Vol. 9 No. 3, 2005, pp. 214-30.

[14]. S. Olsen, J. Wilcox and U. Olsson, Consequences of ambivalence on satisfaction and loyalty, Psychology \& Marketing, Vol. 22, March, 2005, pp. 247-69.

[15]. Y. Yi, and S. La, What influences the relationship between customer satisfaction and repurchase intention? Investigating the effects of adjusted expectations and customer loyalty, Psychology \& Marketing, Vol. 21, May, 2004, pp. 351-73.

[16]. J. M. M. Bloemer and H. D. P. Kasper, The complex relationship between consumer satisfaction and brand loyalty. Journal of Economic Psychology, 16, 1995, 311-329.

[17]. Lovelock, and J. Wirtz, Services Marketing (People, Technology, Strategy, Pearson Prentice Hall, London, 2007).

[18]. R. Oliver, Satisfaction: A Behavioral Perspective on the Consumer (McGraw-Hill, Maidenhead, 1997)

[19]. G.A. Churchill and C. Surprenant, An investigation into the determinants of customer satisfaction", Journal of Marketing Research, Vol. XIX, November, 1982, pp.491-504.

[20]. R. Oliver, A cognitive model of the antecedents and consequences of satisfaction decisions, Journal of Marketing Research, Vol. XVII, November,1980, pp. 460-9.

[21]. Y. Yi, A critical review of consumer satisfaction", in Zeithaml, V. (Ed.), Review of Marketing, Vol. 4, (American Marketing Association, Chicago, IL, 1990) pp. 68-123.

[22]. L. McGuire, Australian Services: Marketing and Management (Macmillan Education, Sydney, 1999) 
[23]. J. Barsky, Customer satisfaction in the hotel industry: measurement and meaning, Cornell Hotel \& Restaurant Administration Quarterly, Vol. 7, 1992 pp. 20-41.

[24]. T.O. Jones, and E.W. Sasser, Why satisfied customers defect, Harvard Business Review, Vol. 73, 1995, pp. 88-99.

[25]. F.F. Reichheld, The Loyalty Effect: The Hidden Force Behind Growth, Profits, and Lasting Value (Harvard Business School Press, Boston, MA, 1996)

[26]. G.H.G. McDougall and T. Levesque, Customer satisfaction with services: putting perceived value into the equation, Journal of Services Marketing, Vol. 14 No. 5, 2000, pp. 392-410.

[27]. R.T. Rust, and R.L. Oliver, Service quality: insights and managerial implications from the frontier, in Rust, R.T. and Oliver, R.L. (Eds), Service Quality: New Directions in Theory and Practice (Sage, Thousand Oaks, CA, 1994)

[28]. J.L. Heskett, E.W. Sasser, and L.A. Schlesinger, "The Service Profit Chain: How Leading Companies Link Profit and Growth to Loyalty, Satisfaction and Value", The Free Press (New York, NY, 1997)

[29]. Gro"nroos, Service Management and Marketing, "A Customer Relationship Management Approach", 2nd ed., (Wiley, Chichester, 2000)

[30]. K. Monroe, Pricing - Making Profitable Decisions (McGraw-Hill, and Maidenhead, 1991)

[31]. V.A. Zeithaml, Consumer perceptions of price, quality and value: a means-end model and synthesis of evidence", Journal of Marketing, Vol. 52, July, 1998, pp. 2-22.

[32]. M.K. Brady and J. Cronin, Some new thoughts on conceptualizing perceived service quality: a hierarchical approach", Journal of Marketing, Vol. 65, July, 2001, pp.34-49.

[33]. S.Y. Lam, V. Shankar, M.K. Erramilli, and B. Murthy, "Customer value, satisfaction, loyalty, and switching costs: an illustration from a business-to-business service context", Journal of the Academy of Marketing Science, Vol. 32 No. 3, 2004, pp. 293-311.

[34]. J. Sweeney, G. Soutar, and L. Johnson, "The role of perceived risk in the quality-value relationship: a study in a retail environment", Journal of Retailing, Vol. 75 No. 1, 1999, pp. 77-105.

[35]. S. Varki, and M.Colgate, "The role of price perceptions in an integrated model of behavioral intentions", Journal of Service Research, Vol. 3 No. 3, 2001, pp. 232-40.

[36]. Y. Wang, H.P. Lo, R. Chi, and Y. Yang, "An integrated framework for customer value and customer-relationship-management performance: a customer-based perspective from China”, Managing Service Quality, Vol. 14, Nos 2/3, 2004, pp. 169-82.

[37]. V. Zeithaml, M. Bitner, and D. Gremler, (2009), Services Marketing - Integrating Customer Focus Across The Firms (McGraw-Hill, Maidenhead, 2009)

[38]. J.L.M. Tam, "Customer satisfaction, service quality and perceived value: an integrative model", Journal of Marketing Management, Vol. 20 Nos 7-8, 2004, pp. 897-917.

[39]. K.L. Keller, "Conceptualizing, measuring, and managing customer-based brand equity", Journal of Marketing, Vol. 57, 1993 , pp. 1-22.

[40]. M.J. Bitner, "Evaluating service encounters: the effects of physical surroundings and employee responses", Journal of Marketing, Vol. 54 No. 2, 1991, pp. 69-83.

[41]. Gronroos, "A service quality model and its marketing implications.” European Journal of Marketing, 18(4), 1984, 36-44.

[42]. N. Nguyen and G. Leblanc, "Corporate image and corporate reputation in customers' retention decisions in services." Journal of Retailing and Consumer Services, 8(4), 1998, 227-236.

[43]. Gronroos, “A service quality model and its marketing implications.” European Journal of Marketing, 18(4), 1984, 36-44.

[44]. P. Kotler, K.L. Keller, S.H. Ang, S.M. Leong and C.T. Tan, Marketing Management: An Asian Perspective (Prentice Hall, Englewood Cliffs, NJ, 2009)

[45]. D.K. Tse, "How much more are consumers willing to pay for higher levels of service? A preliminary survey", Journal of Services Marketing, Vol. 10 No. 1, 2001, pp. 11-17.

[46]. R.T. Rust, and R.L. Oliver, "Service quality: insights and managerial implications from the frontier", in Rust, R.T. and Oliver, R.L. (Eds), Service Quality: New Directions in Theory and Practice (Sage, Thousand Oaks, CA, 1994)

[47]. K.B. Monroe, Pricing: Making Profitable Decisions, 2nd ed., (McGraw-Hill, New York, NY, 1990)

[48]. J.L., Heskett, E.W. Sasser, and L.A. Schlesinger, "The Service Profit Chain: How Leading Companies Link Profit and Growth to Loyalty, Satisfaction and Value", The Free Press (New York, NY, 1997)

[49]. D.J. Curry, and P.C. Riesz, "Prices and price/quality relationships: a longitudinal analysis", Journal of Marketing, Vol. 52, 1988, pp. 36-51.

[50]. G.M. Erickson, and J.K. Johansson, “The role of price in multi-attribute product evaluations", Journal of Consumer Research, Vol. 12, 1985, pp. 195-9.

[51]. D.R. Lichtenstein, P.H. Block, and W.C. Black, “Correlates of price acceptability”, Journal of Consumer Research, Vol. 15 No. 2, 1988, pp. 243-52.

[52]. W.B. Dodds, K.B. Monroe, and D. Grewal, "Effects of price, brand and store information on buyers' product evaluation", Journal of Marketing Research, Vol. 28, 1991, pp. 307-19.

[53]. K.B. Monroe, Pricing: Making Profitable Decisions, 2nd ed. (McGraw-Hill, New York, NY, 1990)

[54]. V.A. Zeithaml, A. Parasuraman, and L.L. Berry, Delivering Quality Service: Balancing Customer Perceptions and Expectations, The Free Press, Zeithaml, V.A. (1988), "Consumer perceptions of price, quality and value: a means-end model and synthesis of evidence", Journal of Marketing, Vol. 52, July, 1990, pp. 2-22. New York, NY.

[55]. Parasuraman, V.A. Zeithaml, and L. Berry, "A conceptual model of service quality and its implications for future research", Journal of Marketing, Vol. 49, Fall, 1985, pp.41-50.

[56]. U. Lehtinen and J.R. Lehtinen, "Service quality- a study of dimensions. Unpublished working paper", Service Management Institute, Helsinki,1982, 439-460.

[57]. R.C. Lewis and B.H. Booms, The marketing aspects of service quality. Emerging Perspectives in Service Marketing, in Berry, L.L., Shostack, G. and Upah, G. (Eds) American Marketing Association, Chicago, 1983, IL 99-107.

[58]. Gronroos, “A service quality model and its marketing implications.” European Journal of Marketing, 18(4), 1984, 36-44.

[59]. Parasuraman, V.A. Zeithaml and L.L. Berry, "A conceptual model of service quality and its implications for future research." Journal of Marketing, 49, Fall, 1985

[60]. Parasuraman, V.A. Zeithaml and L.L. Berry, "SERVQUAL: a multi-item scale for measuring consumer perceptions of service quality", Journal of Retailing, Vol. 64 No. 1, 1988, pp. 12-40.

[61]. Caruana, Service loyalty. "The effects of service quality and the mediating role of customer satisfaction." European Journal of Marketing, 36(7/8), 2002, 811-828.

[62]. V.A. Zeithaml, M.J. Bitner and D.D. Gremler, Services marketing: integrating customer focus across the firm, 4th ed., pp.117,(Singapore: McGraw-Hill, 2006)

[63]. N. Nguyen and G. Leblanc, "Corporate image and corporate reputation in customers' retention decisions in services." Journal of 
Retailing and Consumer Services, 8(4), 2001, 227-236.

[64]. N. O. Ndubisi, "A structural equation modeling of the antecedents of relationship quality in the Malaysia banking sector." Journal of Financial Services Marketing, 11(2), 2006, 131-141.

[65]. C.G.P. Bellini, G.L. Lunardi and J.L. Henrique, "Service quality in banks: Insights from the Brazilian Experience." Journal of Internet Banking and Commerce, 10(3), 2005

[66]. S.S. Andaleeb and C. Conway, "Customer satisfaction in the restaurant industry: An examination of the transaction-specific model." Journal of Services Marketing, 20(1), 2006, 3-11.

[67]. Lymperopoulos, I.E. Chaniotakis and M. Soureli, "The importance of service quality in bank selection for mortgage loans." Managing Service Quality, 16(4), 2006, 365-379.

[68]. W.G. Zikmund, "Business Research Methods, Seventh Edition", Thomson south-Western, Ohio, 2003, pp.427

[69]. W.G. Zikmund, Business research methods, Fourth edition (Oklahoma state University, 1994)

[70]. D.F. Birks and N.K. Malhotra, Business research methods (Third European Edition, 2007)

Appendix One

Table 1: Demographic Factors

\begin{tabular}{|c|c|c|}
\hline Demographic Factors & Variables & Percentage (\%) \\
\hline Age level & 26 to 30 years old & $33 \%$ \\
\hline $\begin{array}{c}\text { Monthly Income } \\
\text { Level }\end{array}$ & RMB 2501 to 3500 & $40.3 \%$ \\
\hline Education Level & Bachelor Degree & $34.5 \%$ \\
\hline
\end{tabular}

Appendix Two

Table 2: Summary of Hypothesis Testing result

\begin{tabular}{|c|c|c|}
\hline Null Hypothesis & Significant & Test results \\
\hline $\mathrm{H} 1_{0}$ : There is no relationship between image and perceived value. & 0.000 & Rejected $\mathrm{H}_{\mathrm{o}}$ \\
\hline $\mathrm{H} 2_{0}$ : There is no relationship between price and perceived value. & 0.000 & Rejected $\mathrm{H}_{\mathrm{o}}$ \\
\hline $\begin{array}{l}\mathrm{H} 3_{0} \text { : There is no relationship between perceived quality in terms of } \\
\text { reliability and customer satisfaction. }\end{array}$ & 0.000 & Rejected $\mathrm{H}_{\mathrm{o}}$ \\
\hline $\begin{array}{l}\mathrm{H} 4_{0} \text { : There is no relationship between perceived quality in terms of } \\
\text { tangibles and customer satisfaction. }\end{array}$ & 0.000 & Rejected $\mathrm{H}_{\mathrm{o}}$ \\
\hline $\begin{array}{l}\mathrm{H} 5_{0} \text { : There is no relationship between perceived quality in terms of } \\
\text { empathy and customer satisfaction. }\end{array}$ & 0.000 & Rejected $\mathrm{H}_{\mathrm{o}}$ \\
\hline $\begin{array}{l}\mathrm{H} 6_{0} \text { : There is no relationship between perceived quality in terms of } \\
\text { responsiveness and customer satisfaction. }\end{array}$ & 0.000 & Rejected $\mathrm{H}_{\mathrm{o}}$ \\
\hline $\begin{array}{l}\mathrm{H} 7_{0} \text { : There is no relationship between perceived quality in terms of } \\
\text { assurance and customer satisfaction. }\end{array}$ & 0.000 & Rejected $\mathrm{H}_{\mathrm{o}}$ \\
\hline $\begin{array}{l}\mathrm{H} 8_{0} \text { : There is no relationship between perceived value and customer } \\
\text { satisfaction. }\end{array}$ & 0.000 & Rejected $\mathrm{H}_{\mathrm{o}}$ \\
\hline $\begin{array}{l}\mathrm{H} 9_{0} \text { : There is no relationship between perceived value and customer } \\
\text { loyalty. }\end{array}$ & 0.000 & Rejected $\mathrm{H}_{\mathrm{o}}$ \\
\hline $\begin{array}{l}\mathrm{H} 10_{0} \text { : There is no relationship between customer satisfaction and customer } \\
\text { loyalty. }\end{array}$ & 0.000 & Rejected $\mathrm{H}_{\mathrm{o}}$ \\
\hline
\end{tabular}

